\title{
Evaluation of Microbial Contamination of Tools Used In Hair Dressing Salons in Michael Okpara University of Agriculture, Umudike, Abia State
}

\author{
Mbaj iuka Chindu Stanley ${ }^{1}$, Obeagu Emmanuel Ifeanyi ${ }^{2}$, Ochei Kingsley \\ Chinedum $^{3}$, Iheke Steve Onyekachi ${ }^{1}$ \\ 'Department of Microbiology,Michael Okpara University of Agriculture,Umudike,Abia State,Nigeria. \\ ${ }_{2}^{2}$ Medical Laboratory Scientist,Diagnostic Laboratory Unit,University Health Services Department, Michael \\ Okpara University of Agriculture,Umudike,Abia State,Nigeria. \\ ${ }^{3}$ H.S.S. and Laboratory Department, FHI 360,Country Office, Plot 1073-A1,Garki Abuja,FCT,Nigeria.
}

\begin{abstract}
This project work was conducted to evaluate the microbial contamination on tools used in hairdressing salons in Michael Okpara University Agriculture, Umudike,Abia State,Nigeria. Samples were collected from two different hairdressing salons inside the campus. The samples were collected from combs, brushes and hairdryers using a moistened swab stick and processed according to standard procedures. All the materials used were obtained from the microbiology and bio-chemistry laboratory except the sample and the culture media used which were prepared according to the manufacturer's instructions. The samples were diluted into sixth quadrants before been inoculated on the media using sticking method. Each plate was incubated at $37^{\circ} \mathrm{c}$ for 24 hours (bacterial) and 48-72hours (fungal). The isolates obtained were examined using biochemical characteristics, colonial morphology and also identified using microscopic examination. The results obtained include Staphylococcus aureus, streptococcus spp and micrococcus spp. Aspergillus spp, mисоr spp and Rhizopus spp. Also, results of the total bacterial and fungal counts were obtained. The presence of this potential pathogen is an indication that hairdressing salons could be contributing to the spread of infection with the campus and also the university community.

Keywords: Hair Dressing Salons, Microbial contamination, Tools used in hair dressing, Pathogens.
\end{abstract}

\section{Introduction}

Hairdressing salons are classified as personal services establishments and such services may pose potential health concerns to their clients including the risk of infection and sometimes injury (Adeleye and Osidi po, 2004; Barn and Chen, 2011). These health risks vary depending on the nature of the service, the tools and equipment that are used, the health status of the clients and service providers as well as the infection control procedures, such as piercing and tattooing are clearly associated with bacterial, viral and fungal infections risks, even non-invasive procedures such as pedicures can result in infection (Stout et al., 2011). It is believed that any service with the potential to break the skin's surface can be associated with infections and infections can then be transmitted to and between clients if proper infection control procedures are not implemented. It has observed that hairdressing operators and their clients are constantly being exposed to bacterial or fungal contamination during their services.

Microorganisms are everywhere including skin surfaces and are continually introduced into the environment and could therefore easily spread between clients and operators and transferred by contact with unwashed hands, soiled equipment or contact with blood and other body substances (De Souza and Shibu , 2004).

Infection can occur during hair dressing procedures since items such as razors, scissors, combs, clippers and hairpins can accidentally penetrate the skin. Blood and body fluids do not have to be visible on instruments, equipment or working surfaces for infection to be transmitted. Infections that can be spread I hairdressing premises include skin infections on the scalp, face and neck such as impetigo and fungal infections such as tinea capitits and ringworm (Brown, 2006: Amodio et al., 2010; Barn and Chen, 2011). Burns can also occur during hair dressing procedures involving hot rollers, tongs and crimpers and when hair is being washed with contaminated water or when stationary or hand-held dryers are improperly used. There are reports of people who have been infected with head lice from direct hair-to-hair contact with someone who has head lice (Ruddy et al., 2011). Unfortunately, there are no established regulations, guidelines and best practices for many of these salons in our environment. Our goal is to protect the health of the public and one important aspect of minimizing health risks is to understand the infection risks of these salons, hence the aim to evaluate microbial contaminations on tools and equipment used in hair dressing salons in selected salons in Michael Okpara University Agriculture, Umudike. 


\section{AIMS AND OBJECTIVES}

To evaluate microbial contamination on tools used in hair dressing salons.

To isolate and identify pathogenic fungi and bacteria associated with hair dressing tools.

To determine the microbiological counts of fungi and bacteria

\section{MATERIALS}

\section{Materials And Method} samples.

All materials used were collected from the microbiology and biochemistry laboratory except the

\section{METHODS}

\section{SAMPLE COLLECTION METHODOLOGY}

Samples were collected from two (2) hairdressing salons in Michael Okpara University of Agriculture, Umudike to determine the types of micro-organisms present in combs, brushes and dryers were sampled with a moistened sterile swab stick. After taking each swab, the swab stick was placed back into the casing to avoid contamination and was labeled appropriately. All the samples collected were transported to the laboratory without any delay for culture and was treated according to standard method of Adeleye and Osidipo (2004).

\section{SERIAL DILUTION}

The samples collected with a moistened sterile swab stick were diluted to sixth quadrant (collecting $1 \mathrm{ml}$ of the diluted sample and $9 \mathrm{ml} \mathrm{s}$ of distilled water appropriately) according to Aneja (2005).

\section{PREPARATION OF CULTURE MEDIA}

All culture media used were prepared according to the manufacturer' instructions.

\section{DETERMINATION OF MICROBIAL CONTAMINATION}

Each of the diluted samples were inoculated on the media (Nutrient agar, Macconkey agar and Mannitol agar) appropriately with a wire-loop using striking method. The plates were incubated at $37^{\circ} \mathrm{c}$ for $24 \mathrm{hrs}-48 \mathrm{hrs}$ ( 1 -2days) for bacteria and fungi 48hrs -1 20hrs (2-5days) according to Adeleye and Osidipo (2004).

\section{GRAM STAINING}

Make a smear of the organism on a grease free glass slide. Allow it to air dry. Flood the smear with crystal violet and gently rinse off the crystal violet with tap water. Flood the smear with iodine, leave for at least three seconds and gently rinse off the iodine with tap water. Decolourize by adding alcohol or acetone to the smear while holding the slide at an angle to allow the decolourizer to drain and rinse off excess decolorizer with tap water. Flood the smear with safranin counter stain and allow it for 30seconds and gently rinse off excess Safranin with tap water. The drain slide is allow to be air dry and grain ne gative (From positive organisms are purple while gramm negative pink.

\section{MOBILITY TEST}

This test was performed to determine motility. The pure isolates in the stock culture were first inoculated into nutrient both to keep the organism inactive o phase. A hanging drop technique was carried out for motility. Drops of the cultures were placed on cover slips and plasticizes placed on slides enough to cover the cover slips. The slides were the gently placed over the drops of the cultures without allowing contact. The slides were quickly inverted, are being taken not to allow drops, from the cover slips to touch the slide.

The preparations were observed under the microscope. Motile organisms were seen, moving from one corner of the cover slip to another while non-motile organisms did not move about. (Stewart and Beswick, 1977).

\section{BIOCHEMICAL TEST FOR CHARACTERIZATION OF THE ISOLATES}

Biochemical test refers to the chemical identification of unknown substances within a living thing. The test quantitatively and qualitatively determines a particular substance lie bacteria, fungi and enzyme with the blood. A biochemical test can be used to diagnose a given disease. It can also be used to find the metabolic properties of bacteria.

The biochemical tests carried out for the identification of the organisms are:

\section{CATALASE TEST}

Three (3) millitres of hydrogen peroxide $(3 \% \mathrm{v} / \mathrm{v})$ solution was disposed into a series of test tubes labeled with the isolate numbers. Using sterile wooden spatula, good growths of the test organisms were 
removed from the plates and immersed into the respective test tubes appropriately.

Budding was observed in organisms that catalase was produced. The absence of bubbles showed catalase negative result (Cruickshank et al., 1975).

\section{OXIDATION FERMENTATION ( O-F) TESTS}

This test was performed to determine whether the isolates metabolize glucose either oxidatively or fermentatively. Hugh and Leifsons O-f medium was used. This method adapted from (Cruickshank et al., 1975). This medium was distilled in distilled water and dispersed into clean dry test tubes in lonel aliquots. The tubes were stopped with cotton wool and aluminium foil, autoclave at $121^{\circ} \mathrm{c}$ for 15 minutes at a pressure of $1.2 \mathrm{~g} / \mathrm{cm}^{2}$. The glucose was sterilized by autoclaving separately and then incorporated into the medium into the tubes. The test tubes and contents were allowed to cool and each for oxidative and 5 tubs for fermentation test, the tubes were sealed with sterile paraffin wax after inoculation thereby creating anaerobic conditions. The two sets of test tubes were incubated at 370c for 7 days. Acid formation shown by the change of colour of the medium from purple to yellow in both tubes indicated a fermentation reaction. The appearance of yellow colouration in tubes not covered by paraffin wax should oxidative metabolism. Gas production was indicated by the collection of gas in the Durham tubes. A negative result was indicated by the absence of colour change.

\section{METHYL RED VOGES PROSKAUER (MRVP) TEST}

The medium is used to test for the end-product of glucose metabolism in bacteria and the method used was adapted from (Cruickshank et al., 1975). The MR positive organism produces acids as their end-products $f$ sugar metabolism. The VP organism produce 2,3 - butanediol or acetyl methyl carbihol from fermentation of pyruvic acid.

The medium was prepared by dissolving $15 \mathrm{~g}$ in 1 litre of deionized water. The medium was then dispensed in $10 \mathrm{ml}$, aliquots into tubes. Sterilization was done by autoclaving at $121^{\circ} \mathrm{C}$ for 15 minutes. On cooling at room temperature, isolates were used to inoculate the medium and incubated at $37^{\circ} \mathrm{C}$ to 48 hours. Some of the tubes inoculated with the bacterial isolates were labeled MR and VP respectively.

The MR test was done by delivering 5 drops of methyl red indicator to broth tubes labeled MR. These gently shaken so that the indicator can be dispensed in the broth. Cherry pink (red) colour formation was taken as MR positive while yellow colouration of methyl red in the broth within seconds will be taken as a negative result.

In the VP test, 6drops of Baritt reagent (alphanaphthol) were added to the broth tubes labeled VP, followed by the addition of drops of $40 \%$ potassium hydroxide. These were gently shaken and left to stand for 10minutes. Positive organisms changed the colour of the medium to pink red while those that did not show colour change were VP negative.

\section{INDOLE TEST}

The test demonstrates the ability of certain bacteria to decompose the anuro acid tryptophane to indole which accumulates in the medium (Cruikshank et al., 1975).

The medium was sterilized by autoclaving at $121^{\circ} \mathrm{C}$ for $15 \mathrm{mi}$ nutes. The peptone water broth tubes were inoculated with the stock cultures of the isolates and incubated at $37^{\circ} \mathrm{c}$ for 48 hours. After incubation, $0.5 \mathrm{ml}$ of Koval's reagent comprising 130amyl alcohol, 150ml; P-Dimethyl-amino benzoaldehyde, 10g and concentrated hydrochloride, $50 \mathrm{ml}$ were added ad shaken gently.

A red ring formation at the surface of the tubes was an indication of a positive test while yellow colouration of the surface layer indicated a negative result.

\section{OXIDASE TEST}

This test depends of the presence in bacteria of certain oxidases that will catalyze the transport of electrons between electron donors in the bacteria and a redox tetramethyl p_phenylene-diamire. The dye will be reduced to a dark purple colour (Cruickshank et al., 1975).

In this test, the oxidase reagent $1 \%$ tetramethyl -P-phenylene-diamire dihydrochloride was used. This was prepared by weighing $1 \mathrm{~g}$ of the solid and dissolving in $100 \mathrm{ml}$ of distilled water. Strips of whatman No.1 filter paper were soaked in a freshly prepared $1 \%$ solution of the reagent. The various isolates were streaked on the watted strips of the filter paper. Deep purple colouration within 10 seconds was taken as rodixase positive while absence of purple colouration indicated a negative oxidase reaction.

\section{CITRATE TEST}

This is a test for the ability of the organism especially the members of the enterobaceteriaceae to utilize citrate as the sole carbon and energy source for growth and ammonium slat as the sole source of nitrogen and also Simmon's citrate agar was used. (Cruiskshank et al., 1975). Slants of Simmon's citrate agar 
medium in tubes were inoculated with sterile wire loops containing the test organisms. The tubes were

incubated at $37^{0} \mathrm{C}$ for 96 hours. A positive result was indicated by a change in colour from green to blue while the retention of the original green colour showed citrate negative reaction.

\section{COAGULASE TEST}

This test was used to distinguish staphylococcus aureus (coagulase positive) from Staphylococcus epidermidis and Staphylococcus saprophyticus (coagulase negative). The test was carried out using the tube coagulase technique (DIFCO) capable of demonstrating both free and bound coagulase.

Tube coagulase: In the tube coagulate method, human plasma was diluted 1 in 10 using normal saline as diluent. One milliliter of the diluted plasma was added to $0.1 \mathrm{ml}$ of a 24 hour nutrient broth culture of the organism. The mixture was indicated by the formation of a solid clot $\mathrm{h}$ within the tube while there was no clot formation in the coagulase negative isolates.

\section{SUGAR FERMENTATION TEST}

Peptone water was supplement with $0.015 \mathrm{~g}$ of Bacto-Brews-Cresol as an indicator. This served as a base medium. Then $1 \%$ of the respective carbohydrates such as glucose, sucrose, lactose and mannitol were added. This was stirred to dissolve completely over a Bunsen burner. It was then disposed into test tubes in $5 \mathrm{ml}$ aliquots Durham tubes added in inverted position. This was then plugged with cotton wool and sterilized at $121^{\circ} \mathrm{C}$ for 15 minutes.

About $5 \mathrm{ml}$ of the sugar medium was inoculated with the test organism and incubated at $37^{\circ} \mathrm{C}$ for 24hours. A change in colour from purple to yellow indicated acid production due to the fermentation of the sugar while retention of the purple colour indicates negative reaction (this is no sugar fermentation). Gas production was shown by the presence of bubbles in the inverted Durham tubes.

\section{Result}

The results of the microbial analysis reveal the presence of some micro-organisms in the sample. 3.1 TABLE

\section{1: RESULT OF THE BIOCHEMICAL TEST}

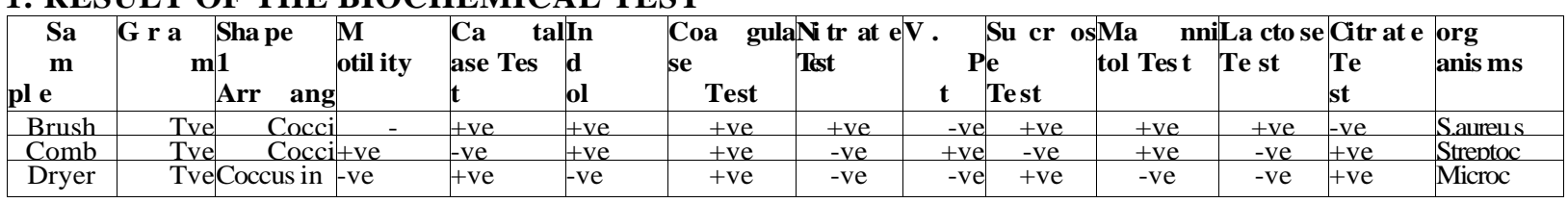

Key: +ve $\quad-\quad$ Shows that the test is positive

-ve - Shows that the test is negative

3.2 TABLE 2: DISTRIBUTION OF ROLE OF ORGANISMS IN THE SAMPLES.

\begin{tabular}{|l|l|l|l|l|l|l|}
\hline Sample & Bacterial Isolate & Fugal isolates & Mucor & Rhiz. \\
\hline S/No & Staph & Strep & Micro & Asp & Much & + \\
\hline Brush & + & + & + & + & - & + \\
\hline Comb & + & + & + & + & + & + \\
\hline Dryer & + & + & + & + & + & + \\
\hline
\end{tabular}

Key: $\quad+\quad$ Means there is growth

Staph Means there is no growth

Strep Means Streptococcus sp

Micro Means Micrococcus sp

Asp Means Aspergillus sp

Mucor Means Mucor sp

Rhiz Means Rhizopus sp 


\section{TABLE 3: CULTURAL CHARACTERISTICS OF BACTERIAL ISOLATES}

\begin{tabular}{|l|l|l|l|}
\hline (S/N) Isolates & Colony Morphology & Microscopy & Suspected Organisms \\
\hline 1 & $\begin{array}{l}\text { Large creamy white colony which are non- } \\
\text { haemolytic }\end{array}$ & Round, convex with a sharp border & Staphylococcus aureus \\
\hline 3 & Smelling creamy haemolytic colony & $\begin{array}{l}\text { Lancet shape and mucoid glistening } \\
\text { colonies. }\end{array}$ & Streptococcus spp \\
\hline & Red and white colonies which are & $\begin{array}{l}\text { Spore formed rods produced which are } \text { Micrococcus spp } \\
\text { dry, fland irregular-with labate margins. }\end{array}$ & \\
\hline
\end{tabular}

\subsection{TABLE43: CULTURAL CHARACTERISTICS OF FUNGI ISOLATES}

\begin{tabular}{|c|c|c|c|}
\hline (S/N) Isolates & Colony Morphology & Microscopy & Suspected Organisms \\
\hline 1 & $\begin{array}{l}\text { Black powdery myceliated spreading and } \\
\text { zonated colonies. }\end{array}$ & $\begin{array}{l}\text { Well branched with colourless but } \\
\text { septate, hyphae and black conidia } \\
\text { borne on storigmata }\end{array}$ & Asp \\
\hline 2 & $\begin{array}{l}\text { White wooly mass of mycelia spreading and } \\
\text { covering the petri-dish within } 2-3 \text { days. }\end{array}$ & $\begin{array}{l}\text { Filamentous, non-septate, hypae with } \\
\text { black spots at tips. }\end{array}$ & Mucor Spp \\
\hline 3 & $\begin{array}{l}\text { Yellowish grey hypae with some black dots } \\
\text { at the centre }\end{array}$ & $\begin{array}{l}\text { Filamentous, non-septate dots, at the tip } \\
\text { of hypae. }\end{array}$ & Rhizopus Spp \\
\hline
\end{tabular}

TABLE 5: TABLE BACTERIAL COUNT (CFU/

\begin{tabular}{|c|l|l|l|l|}
\hline (S/N) & Plate 1 & Thate II & Average \\
\hline Brush 185 & 180 & 365 & 182.5 \\
\hline Comb 165 & 154 & 189 & 319 & 159.5 \\
\hline Dryer 194 & & 385 & 192.5 \\
\hline
\end{tabular}

The serial dilution used was sixth quadrant $\left(10^{6}\right)$ Tvc $($ cfulg $)=1$ X N X df

$\mathrm{V}$

TVC (cfulg) - $1 \times 3 \times 10^{6}$

$0.1=30,000,000 \mathrm{cfulg}$

3.6 TABLE 5: TABLE BACTERIAL COUNT (CFU/g)

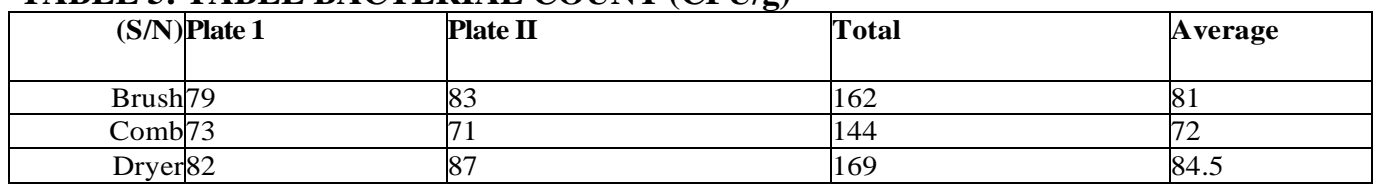

The serial dilution used was sixth quadrant $\left(\mathbf{1 0}^{4}\right) \mathrm{Tvc}(\mathrm{cfulg})=1 \mathrm{X}$ N X df

$\mathrm{V}$

TVC (cfulg) - 1 X $3 \times 104$

$0.1=300,000$ cfulg

\section{Discussion}

The three (3) samples obtained from different hairdressing salons, only three (3) bacterial and three (3) fungal species were isolated.

Table 1 shows the result of the biochemical test. These indicates the positive and negative result of the biochemical test, shape or arrangement of the isolate, show whether the isolate is a gram positive or negative organism and also specified or identified the type of organism.

Studies have examined the presence of potential pathogens as well as infection control practices of personal service establishments such as salon so as to better understand and characterize potential hazards in salons (Secular et al., 2002).

Table 2, shows the distribution rate of the organisms in the samples. Here, three (3) bacterial potential pathogenic species and three (3) potential pathogenic fugal species were isolated from different hairdressing salons. Staphylococcus aureus and streptococcus spp were isolated from all he salons and are among the most important bacteria that cause disease in humans. This bacterial has been shown to cause various pus-forming diseases in humans such as boils, carbuncles, folliculitis, impetigo contagiosa, scalded-skin syndrome. Isolation of the organisms from the equipment and tools used in these hair-dressing salons indicate that the sterilization methods employed by the operations are not effective if at all they sterilize items between clients.

The fungal isolated such as Aspergillus Spp, Mucor Spp and Rhizopus Spp in some samples also indicates that infection like ringworm or dematophtosis can also be spread via these salons. From these 
findings, it is clear that hygienic practices in these hairdressing salons are far below expected standards.

Table 3 and 4 shows the cultural characteristic of bacterial and fungal isolates or suspected organisms. Here, these show the colony, morphology and microscopy of the suspected organisms on bacterial and fungal isolates. Due to the presence of these potential pathogens, the authors concluded that current disinfection techniques used at each salon were inadequate in preventing health risks among clients. It has been observed that sterilization techniques differ between service providers with $38 \%$ reporting the use of ultrasonic cleaners, all of which are not approved method of sterilization in many jurisdictions (Rideout, 2010).

Table 5 and 6 shows the result of the total bacterial and fungal counts of the isolate. These show the total count of the distribution rate of the isolate.

Despite these limitation, this work provide important information, the potential risk associated with salon services in Michael Okpara University of Agriculture, Umudike and the possibility of salons acting as source of infection among clients and also to the school in general. Furthermore, customers therefore are called upon to make sure that any salon, equipment and tools to be used on them must be properly sterilized to their satisfaction or according to the standard of sterilization method.

\section{Conclusion}

Hairdressing salons are personal service to their client including the risk of infection and sometimes injury. This study or work indicates that hairdressing salons can be characterized as hazards which can leads to the spread of infection to human, due to untreated tools and equipment used in hairdressing salons. However, hairdressers must treat their hair tools and equipment before been used to their clients or customers, in order to reduce the rate of infection.

\section{References}

[1]. Adeleye, I.A and Osidipo, O.O. (2004). "Isolation and Characterization of Micro-organism form Instrument Used by Pedicurists Operating within Larger Metropolis, Nigeria". West Ind. Med. Journal. 53:413-415.

[2]. Amodio, E. Benedetto, M.A., Gennaro, L., Maida, C.M. and Romano, N. (2010). "Knowledge, Attitudes and Risk of HIV, HBV and HCV Infections in Hairdressings of Palermo City". Europe Journal Public Health 20:433-437.

[3]. Aneja, K.R. (2005) "Experiments in Microbiology, Plant Pathology and Biochemistry. New Age Publishing Press. 69 ISBN B1-224494.

[4]. Barn, P. and Chen. T. (2011). "Infections Associated with Personal Service Establishments: Aesthetics". National Collaborating Centre for Environment Health ISBN :978-1-926933-29-Opp.1-10.

[5]. Brown, N.J. (2006). "Guideline for Public Health Standards of Practice for Hairdressing, $2^{\text {nd }}$ Edition” ISBN:0738956521 Australia PP.1-4.

[6]. Cruckshank, Este Alwet and Steve, J. (1975) "Biochemcial Test" 18:2

[7]. De Souza, B.A. and Shibu, M.M. (2004) "Infections and Respiratory Hazards of Nacl-sculpture Plast". Reconstr. Surg:114:10041008 .

[8]. Rideout, K. (2010) “Comparison of Guidelines and Regulatory Frameworks for Personal Services Establishments.” Vancouver , BC: National Collaborating Centre for Environment Health .www.ncceh.ca

[9]. Ruddy, M., Cummins, M., Drabu, V. (2001). Hospital Hairdresser as a Potential Source of Cross-infection with MRSA. Journal hospital infection. 49-225-227.

[10]. Secular, F., Akintunde, C. and Amodio, E. (2005) "Hazard in Hair Dressing Salons" 98(2)42-46.

[11]. Stewart and Beswick (1977) "Motility Test" 53(1) 4-5)

[12]. Stout, J.E, Gadowski, L.B., Rath, S. Alspaugh, J.A., Miller M.B and Cox, G.M. (2011). "Pedicure-Associated Rapidly Growing Mycobacterial Infections. An academic Disease" Clinical Infection Disease, 53:787-792. 